\title{
Antenatal folic acid and vitamin D supplement use: data from the SCOPE Ireland pregnancy cohort study
}

\author{
K. O’ Callaghan ${ }^{1,2}$, Á. Hennessy ${ }^{1}$, L.C. Kenny ${ }^{2}$ and M. Kiely ${ }^{1,2}$ \\ ${ }^{1}$ Vitamin D Research Group, School of Food and Nutritional Sciences and ${ }^{2}$ The Irish Centre for Fetal and Neonatal \\ Translational Research, University College Cork, Ireland
}

Data in Irish women show low compliance with periconceptual folic acid supplementation guidelines, which are strongly associated with socio-demographic background ${ }^{(1)}$. There are currently no recommendations for vitamin D supplementation during pregnancy in Ireland. The aim of this study was to describe the prevalence of nutritional supplement use, with particular attention to folic acid and vitamin D, in women participating in the Screening for Pregnancy Endpoints (SCOPE) Ireland prospective cohort study.

Participants (n 1768) were healthy, nulliparous women, having a singleton pregnancy and receiving antenatal care in the Cork University Maternity Hospital. Women provided written informed consent during their first trimester and completed a series of clinical and questionnaire-based assessments at 15 and 20 weeks' gestation ${ }^{(2)}$. Brand-level data on the use of nutritional supplements were reported pre-conception, throughout the first trimester and at 15 weeks' gestation.

Statistical analysis was conducted using SPSS $^{\circledR}$ version $20 \cdot 0$ (SPSS, IBM). Prevalence data were compared using Pearson Chi-Square. $P<0.05$ was considered statistically significant.

Folic acid supplementation was reported by $70 \%$ of women prior to conception, which increased to $99 \%$ during the first trimester and then decreased to $65 \%$ at 15 weeks' gestation. Among supplement users, the median (IQR) folic acid dose was $400(0) \mu \mathrm{g}$ per day. Overall, $97-99.5 \%$ of supplement users met the RDA of $400 \mu \mathrm{g}$ per day ${ }^{(3)}$.

At 15 weeks' gestation, $36 \%$ of women were taking a multivitamin product, which represented an increase of $13 \%$ from the preconception prevalence.

Overall, $41 \%$ obtained vitamin D in supplemental form from a combination of multi-vitamins, fish oils and vitamin D supplements. The mean (SD) vitamin D intake from supplements was 5.0 (1.5) $\mu \mathrm{g} / \mathrm{d}$ at 15 weeks' gestation.

\begin{tabular}{|c|c|c|c|c|c|c|c|c|}
\hline \multirow[b]{3}{*}{$\mathbf{N}$} & \multicolumn{4}{|c|}{ Folic acid } & \multicolumn{4}{|c|}{ Multivitamin } \\
\hline & \multicolumn{2}{|c|}{ Pre-conception } & \multicolumn{2}{|c|}{ First trimester } & \multicolumn{2}{|c|}{ Pre-conception } & \multicolumn{2}{|c|}{ First trimester } \\
\hline & $\begin{array}{l}\text { Users } \\
1242\end{array}$ & $\begin{array}{l}\text { Non-users } \\
526\end{array}$ & $\begin{array}{l}\text { Users } \\
1751\end{array}$ & $\begin{array}{l}\text { Non-users } \\
17\end{array}$ & $\begin{array}{l}\text { Users } \\
410\end{array}$ & $\begin{array}{l}\text { Non-users } \\
1358\end{array}$ & $\begin{array}{l}\text { Users } \\
546\end{array}$ & $\begin{array}{l}\text { Non-users } \\
1222\end{array}$ \\
\hline Age $\leqslant 25$ y $(\%)$ & $3 \cdot 1$ & $31 \cdot 6^{*}$ & $11 \cdot 2$ & $52 \cdot 9^{*}$ & 4.9 & $13 \cdot 6^{*}$ & $7 \cdot 3$ & $13 \cdot 5^{*}$ \\
\hline Age $\geqslant 35$ y $(\%)$ & 15.9 & $7 \cdot 2^{*}$ & $13 \cdot 4$ & 5.9 & $17 \cdot 3$ & $12 \cdot 1^{*}$ & 15.4 & $12 \cdot 4$ \\
\hline University education $(\%)$ & $54 \cdot 6$ & $31.9^{*}$ & $48 \cdot 0$ & $35 \cdot 3$ & $56 \cdot 6$ & $45 \cdot 2^{*}$ & $54 \cdot 8$ & $44 \cdot 8^{*}$ \\
\hline Obese $(\%)$ & $11 \cdot 8$ & $13 \cdot 7$ & $12 \cdot 2$ & $29 \cdot 4$ & $11 \cdot 7$ & $12 \cdot 5$ & $10 \cdot 8$ & $13 \cdot 0$ \\
\hline Smoking at 15 weeks $(\%)$ & $4 \cdot 8$ & $22 \cdot 2^{*}$ & 9.8 & $35 \cdot 3^{*}$ & $7 \cdot 1$ & $10 \cdot 9^{*}$ & $6 \cdot 0$ & $11 \cdot 8^{*}$ \\
\hline Alcohol at 15 weeks $(\%)$ & $15 \cdot 2$ & $19 \cdot 4^{*}$ & $16 \cdot 6$ & $5 \cdot 9$ & $17 \cdot 3$ & $16 \cdot 2$ & $18 \cdot 3$ & $15 \cdot 6$ \\
\hline
\end{tabular}

* Denotes significant difference between users and non-users $(P<0.05)$

In this large, well-characterised pregnancy cohort, almost one third of women did not report preconception folic acid supplementation use, although it increased substantially during the first trimester of pregnancy. The prevalence of antenatal multivitamin use is low and is the major contributor to supplemental vitamin D. Women who are non-smokers, above 35 years of age and who have a university education are more likely to take a multivitamin supplement during pregnancy and to be compliant with periconceptual folic acid recommendations.

1. Tarrant RC, Sheridan-Pereira M, McCarthy RA, et al. (2011) Ir Med J 104, 173-7.

2. McCowan LM, Roberts CT, Dekker GA, et al. (2010) BJOG 117, 1599-607.

3. Health Promotion Unit of Department of Health (1995) What every woman needs to know about the prevention of neural tube defects spina bifida and anencephaly. Dublin: Department of Health. 